acute hospitals, contributes most to the prevention of progression of disease even if it is unable to prevent the onset of disease. In practice, so-called preventive medicine contributes very little to the prevention of ill health.

IEUAN DAVIES

Postgraduate Medical Centre,

Raigmore Hospital,
Inverness IV2 3UJ

${ }^{1}$ Davies IJT. Br Med F 1978;i:104-5.

\section{Where have all the nurses gone?}

SIR,-I feel that many of the writers who have so far contributed to the correspondence (9 February, p 406; 16 February, p 486) about "Where have all the nurses gone?" (19 January, p 199) have shown a degree of emotion which is totally inappropriate, and also that doctors are always very anxious to correct the deficiencies in nursing without looking at their own failings. Furthermore, it is impossible to be aware of the work entailed in any job unless one has been the job-holder. A number of erroneous statements have been made by your correspondents, and I would like to correct these.

Firstly, nursing is not a profession in the true sense of the word, and our medical colleagues are frequently the first to ensure that it is not regarded as such. Secondly, it is untrue to say that doctors are no longer asked to give lectures to nurses. They are asked very frequently but often decline the offer. In addition, some of the lectures which are presented are of such poor quality that those who deliver them are not requested to repeat their performances. The "myriads" of nurse tutors to which reference was made in one letter spend a great deal of their time attempting to cajole truculent physicians and surgeons into sharing their knowledge with nursing colleagues. These tutors also spend many hours interpreting those lectures which are incomprehensible to their students.

I would like to state that, contrary to common thought, most nurses find the role of the nursing officer to be ambiguous. I am sad to say, however, that when I attempted to warn one of the consultants with whom I worked in 1966 that the outcome of "Salmon" would not be favourable he accused me of overreacting. With regard to the reduction in working hours, most nurses, again, consider it unnecessary.

Finally, may I ask doctors to consider their attitudes towards nurses, and the pressure of work to which they subject them. If some attention were paid to both of these, not only would relationships improve but more of us might continue to practise the skills in which we were trained.

London SE1 4JF

Pamela M JefFeries

\section{Medical advisory machinery}

SIR,-The debate on medical advisory machinery in the National Health Service promises to be one of the major issues for the Association in 1980. I would remind your readers that the issue was referred to Council after a full debate in the Northern Regional Council last October. I am grateful that the matter has been fully reported in your journal (9 February, p 418). What are the main issues at the present time?
(1) Health authorities have been receiving medical advice which is fragmented, duplicated, and indeed triplicated. Doctors have complained of the tremendous amount of time being spent debating and redebating the same issues in different committees. (2) Health authorities would certainly welcome one channel of professional advice that they could regard as the voice of authority from the profession. (3) The British Medical Association, enjoying great authority within the profession and even greater authority outside it, is singularly well equipped to offer that advice and to provide the necessary advisory machinery. (4) The debate in Council demonstrated that the issue was divisive, but $D$ Ralph Lawrence made the cogent point when he said that "the future of the Association lay in the periphery but the divisions were doing less and less."

The divisions will become more active only if more business is channelled through them, and the taking on of an advisory function no only will strengthen the division but at the same time will boost the membership. True, the divisional structure will have to be so arranged that all crafts are represented therein but this is a minor issue. Non-members will observe the scale and quality of the business being channelled through divisions; they will not only be ready and anxious to join the Association but would also be prepared to play a full and active role in Association affairs.

In the North of England the Association has always had a strong political role. I am well aware that this position does not obtain everywhere, and this may well be reflected in the attitudes of some members of Council. If at the end of the day the local BMA division does not become the sole source of medical advice at the very least its right to be consulted must be written into the new advisory structure.

I hope that this major issue will become a topic of lively debate up and down the country.

LiONEL Kopelowitz

Newcastle upon Tyne NE3 4BP

\section{An effect of inflation}

SIR,-Three years ago I bought my present car for $£ 1740$. Today I was offered $£ 1800$ in part exchange for an identical but new car These now cost $£ 3800$ with delivery charges, number plates, etc.

In many ways, I am fortunate to be offered so good a price, but it does make nonsense of the fact that my accountant has been allowing me $25 \%$ of the remaining value of my car as depreciation each year, on which I am allowed tax relief as I use my car for professional purposes. I will now have to pay back my tax relief, although in practice I need to find $£ 2000$ to get the same car new.

I hope that our negotiators will bear this effect of inflation in mind.

Harlow, Essex CM18 7LU

JOHN TROWELL

\section{Domiciliary visits by consultants}

SIR,-I read with interest the letter from Dr P E Jackson (26 January, p 256) regarding domiciliary visits by consultants, and would like to support the views expressed by him.

Here the communication and discussion with the patients' general practitioners is of the utmost importance in deciding which patients need an immediate hospital admission, as an emergency, and which patients can be seen and assessed by the consultant in his outpatient clinic. There are outpatient clinics once or twice a week in every specialty in the hospital, and in the specialty of rheumatology they are held four or five times a week. In this way much valuable time of the consultant can be saved, which he can devote to the care of his patients, and to teaching, instructing, and supervising the work of the junior medical staff. This also saves considerable money for the National Health Service.

In my view, the only occasion when a consultant wants to do a domiciliary visit is when he wishes to see the patient who is physically too ill to travel in his domestic and social environment to assess the nature of his disability, and his need of the other social services, so as to keep him at home as long as possible to save an acute hospital bed. Such occasions, however, are few and far between.

I know a number of consultants who do not undertake domiciliary visiting of patients, and there are a number of area and regional health authorities who do not insist that they do so.

M A KHAN

Department of Rheumatology and

Rehabilitation,

Royal Northern Hospital,

London N7 6LD

\section{Inner city GPs}

SIR,-Although I am sympathetic to Dr G E Crawford's suggestions (16 February, p 500) for attracting general practitioners to our declining inner cities, my experience as chairman of the area health authority's planning team for primary care in Liverpool is that the barriers to their implementation are by no means always as local as he implies. While I would not underestimate the importance of local authority co-operation in the provision of suitable premises, their financing has been considerably hindered by the Government's effective withdrawal of the annual capital allocation for primary care schemes, with the result that the situation has altered from one of postive discrimination to one of open competition with secondary care and other capital schemes in the regional programme.

In the current financial climate the Department of Health and Social Security, must pay more than lip service to developing the community sector if any real shift of resources is to occur. Major investment is a prerequisite to achieving revenue savings through community care, but neither bridging finance ${ }^{1}$ nor a revenue investment programme, ${ }^{2}$ one of which would be required to effect this, has ever been forthcoming.

A number of incentives to recruitment, like the special payments to older practitioners making way for younger ones which $\mathrm{Dr}$ Crawford suggests, have been put forward in recent times. These have included salaried appointments; limited list sizes; catchment areas and populations; a compulsory retirement age for inner city GPs; the attachment of trainees to elderly single-handed practitioners, with a guarantee that they will "inherit" the practice on the incumbent's retirement; weighting of capitation payments for "highdependency" groups such as the handicapped; financial incentives (on the lines of the type D allowance) linked to inner city practices; and 